\title{
CONTEXTUALIZING PROFESSIONAL RESPONSIBILITY: A NEW CURRICULUM FOR A NEW CENTURY
}

\author{
Mary C. Daly, Bruce A. Green, ${ }^{* *}$ AND Russell G. PearCe ${ }^{* *}$
}

INTRODUCTION

The teaching of professional responsibility in U.S. law schools is entering a new age. A relative newcomer to the traditional curriculum, professional responsibility has struggled over the past twenty-one years to establish its intellectual legitimacy. It has evolved from a cramped course on the codes of lawyer conduct adopted by the American Bar Association ("ABA") to an expansive course on the law of lawyering. The premise of this essay is that professional responsibility has matured as a subject matter to the point where a new genre of courses should join the pervasive method and the traditional survey course.

The richness and complexity of the subject matter demand an exploration greater than most law school curricula presently offer. The new age of professional responsibility will reflect this intellectual maturity through the introduction of contextual courses that are designed to nurture the development of reflective ethical judgment. These courses will be offered in addition to the pervasive method, in lieu of the traditional survey course, or as a supplement to them in the form of an upperclass elective. Contextual courses explore ethical dilemmas in the context of a single practice area (such as corporate, public interest, or criminal law) and in multiple employment settings (such as law firm, in-house, government agency, or prosecutors' offices). The individual topics covered in contextual courses are quite similar to those in traditional survey courses; however, contextual courses bring a sense of immediacy and coherence to professional responsibility that too often is missing from the traditional survey courses in which practice and substantive-law settings change from page to page.

\footnotetext{
Copyright $(\mathcal{C} 1996$ by Law and Contemporary Problems

* Professor of Law and Director of the Stein Institute of Law and Ethics, Fordham University.

** Professor of Law and Director of the Stein Center for Ethics and Public Interest Law, Fordham University.

*** Associate Professor of Law and Associate Director of the Stein Center for Ethics and Public Interest Law, Fordham University.
} 
As explained below in more detail, Fordham Law School has offered contextual courses for the past several years, in addition to the traditional survey course. We have found them to be extremely effective and rewarding pedagogical tools. From the students' perspective, the courses' readings and classroom discussions are highly stimulating. The single practice-area, multipleemployment framework captures the students' moral imagination because it almost invariably relates to their career interests. The students' engagement is greater at all levels of instruction. They are eager not only to learn the rules governing lawyers' conduct but also to debate the underlying public policies. Discussions of the rules' economic, political, and social consequences foster greater personal reflection. From our perspective, the contextual courses operate synergistically on our teaching and scholarship. The students' enthusiasm reinforces our own, raising the intellectual content of classroom lectures, problem-solving, and discussions. Since we each write in areas closely related to the contextual courses we teach, it is easier to bring our scholarship into the classroom, and our students' responses and suggestions often lead us to explore new paths and ideas in our writing. We are particularly proud of the accolades our contextual courses have won from Judge Oakes of the United States Court of Appeals for the Second Circuit:

More law schools should follow Fordham's innovative lead in offering a varied and rich curriculum in professional responsibility. . . Only by offering a variety of teachers and courses can law schools foster the intra-law school intellectual stimulation that is so important to good teaching. Through such offerings, the law school can send out the proper signals, upgrade the teaching in this rich area, and help instill a respect for standards that are higher than the minimal norms required by the rules governing professional conduct in most states. ${ }^{1}$

\section{A Brief OVerview of PAST ANd PResent Methods}

Prior to 1974 , professional responsibility was a cipher in most law school curricula. If a school did offer a course, neither the faculty nor the students took it seriously. Readings and discussions rarely went beyond platitudes about professionalism and warnings against commingling funds. In response to the Watergate scandal, the ABA adopted Standard 302(a)(iii) in 1974, mandating the teaching of professional responsibility in all ABA-accredited law schools. ${ }^{2}$ Most law school faculties responded in a manner that psychologists would label

1. James L. Oakes, Commentary on Judge Edwards' "Growing Disjunction Between Legal Education and the Legal Profession," 91 MICH. L. REV. 2163, 2166 (1993).

2. STANDARDS FOR THE APPROVAL OF LAW SCHOOLS Standard 302(a)(iii) (Amer. Bar Ass'n 1974) (providing that accredited law schools must "require for all student candidates for a professional degree instruction in the duties and responsibilities of the legal profession"). For excellent historical overviews of the teaching of professional responsibility in U.S. law schools, see James E. Moliterno, $A n$ Analysis of Ethics Teaching in Law Schools: Replacing Lost Benefits of the Apprentice System in the Academic Atmosphere, 60 U. CIN. L. REV. 83 (1991); Deborah L. Rhode, Ethics by the Pervasive Method, 42 J. LEGAL EDUC. 31 (1992). See generally Harry W. Jones, Lawyers and Justice: The Uneasy Ethics of Partisanship, 23 VILL. L. REV. 957,959 (1978). 
"passive-aggressive.". Like John Dean himself, ${ }^{3}$ the faculties doubted that attendance at an ethics course would have altered the behavior of the lawyerparticipants in the scandal. At a more primitive, political level, they resisted the ABA's assertion of curricular authority for territorial reasons, viewing it as a threat to academic autonomy. As one prominent law school dean commented, "I resent it. I resent the imposition of the bar, telling us how to do it." Rather than formally objecting to the ABA's directive, however, law schools signaled the course's second-class status within the curriculum by assigning it minimal credit, by making it a rite-of-passage course for junior faculty, or by hiring local attorneys as adjunct faculty members to teach the course. ${ }^{5}$

Law students had little difficulty understanding these signals. They dismissed the course as irrelevant and displayed their convictions with low rankings and savage comments on course evaluations. ${ }^{6}$ A 1979 survey documented the students' low esteem for professional responsibility courses and their perception of the courses as "requiring less time, as substantially easier, as less well taught, and as a less valuable use of class time" than their other courses. Faculty members often reinforced their students' attitudes (or at least did nothing to dispel them), labeling the course as a doomed attempt to infuse morality or condemning its content as "practice" not doctrine. Law schools rarely considered hiring more than one professor to teach ethics full-time. The National Council of Bar Examiners and regulatory bodies reinforced the message by imposing the passage of the Multi-State Professional Responsibility Examination ("MPRE") as a condition of admission to the bar. Studying for the MPRE requires a mastery of cognitive dissonance, both as to content and

3. When asked if he would have responded any differently to the events of Watergate if he had studied professional responsibility in law school, Nixon's White House Counsel John Dean, replied, "No, I don't think so. ... I knew that the things I was doing were wrong, and one learns the difference between right and wrong before one enters law school. A course in legal ethics wouldn't have changed anything." Thomas Lickona, What Does Moral Philosophy Have to Say to the Teacher of Ethics?, in Ethics Teaching IN Higher Education 129 (Daniel Callahan \& Sissela Bok eds., 1980). For a discussion of common faculty criticisms of professional responsibility courses, see Robert M. Ackerman, Law Schools and Professional Responsibility: A Task for All Seasons, 88 DICK. L. REV. 202 (1984).

4. K.C. Cole Janssen, "We'll Murder Them In August": Who Decides How Ethics Should Be Taught?, 4 JURIS DR. 19, 20 (Jul.-Aug. 1974) (quoting Dean Wiley H. Davis of the University of Arkansas School of Law). A measure of peace between the warring factions was achieved by including in Standard 302(a)(iii) the statement that "such required instruction need not be limited to any pedagogical method as long as the history, goals, structure and responsibilities of the legal profession and its members, including the ABA Code of Professional Responsibility, are all covered." Id.

5. Rhode, supra note 2 , at 40.

6. Surveyors of the field commonly report statements such as the following: "For many people, at best it's a blowoff course, one that can be skipped often and without guilt," Rosemary C. Harold, Dilemmas: Ethics Are Lawyers' Biggest Concern-So Why Isn't There Any Rational Way to Teach Them in Law School?, STUDENT LAW., Dec. 1989, at 9; "[M]andatory professional responsibility courses are not as rigorous or interesting as other substantive law courses ... , "Lawrence A. Dubin, Professionalism Among Lawyers: The Law School's Role, 68 MICH. B.J. 850, 851 (1989); they are the "dog" of the curriculum, "hard to teach, disappointing to take, and often presented to vacant seats or vacant minds," Dale C. Moss, Out of Balance: Why Can't Law Schools Teach Ethics?, StUdent LAw.., Oct. 1991, at 19.

7. Ronald M. Pipkin, Law School Instruction in Prófessional Responsibility: A Curricular Paradox, 1979 AM. B. FOUND. RES. J. 247, 258. 
format. Unlike most bar examinations, it wholly disregards state law. ${ }^{8}$ The MPRE tests applicants on their knowledge of the ABA's Model Code of Professional Responsibility and Model Rules of Professional Conduct, flagrantly ignoring the critical fact that the state codes governing lawyers' conduct depart significantly from the ABA models and from one another. Its multiple-choice format sends the misguided message that ethical dilemmas are capable of clear, correct resolution. Presumably, only "core" areas of the law such as torts, property, and constitutional law are sufficiently complex to merit essay examinations and testing after graduation. ${ }^{9}$

The early teachers of professional responsibility approached each semester dually challenged, by apathetic or hostile students and by their colleagues' and the bar's low regard for the subject matter. These challenges, however, unleashed an enormous reservoir of intellectual energy. In an initial quest for legitimacy, most of the energy was poured into new teaching methodologies. Striving to overcome student resistance, professional responsibility teachers first integrated audiovisual materials into their courses. ${ }^{10}$ They later mastered the art of videomaking, producing their own vignettes. ${ }^{11}$ Problem-solving was used to engage students' reasoning; ${ }^{12}$ role-playing was used to engage their emotions; ${ }^{13}$ and literature was used to engage their imaginations. ${ }^{14}$

Outside the classroom, a scholarly community coalesced. The American Association of Law Schools ("AALS") Section on Professional Responsibility played a key role by fostering exchanges between experienced and new teachers at its annual meetings and initiating professional development workshops to advance teaching and encourage scholarship. The ABA's Center on Profession-

8. National Conference of Bar EXAminers, Multistate Professional ResponsibiLITY EXAMINATION: 1996 INFORMATION BULLETIN 28 (1995).

9. With the exception of Florida, the states that require the MPRE permit students to take the examination before they graduate and without having enrolled in or successfully passed a professional responsibility course in law school.

10. For an exhaustive compilation of video resources, see ROGER C. CRAMTON, AUdIOVISUAL Materials on PROFESSIONAL RESPONSIBILITY (1987).

11. See, e.g., Dubin, supra note 6 , at 852 (describing "What Went Wrong? Conversations with Disciplined Lawyers," a video documentary produced by the author, a professor at the University of Detroit School of Law).

12. E.g., Robert H. Aronson, Problems in Professional Responsibility (1978); StePhen GILLERS \& NORMAN DORSEN, REGULATION OF LAWYERS: PROBLEMS OF LAW AND ETHICS (1st ed. 1985); Thomas D. MORgan \& Ronald D. Rotunda, Problems AND MATERIALS ON Professional RESPONSIBILITY (1st ed. 1976); MORTIMER D. SCHWARTZ \& RICHARD G. WYDICK, PROBLEMS IN LEGAL ETHICS (1st ed. 1983). Professional responsibility instruction based on problem-solving has not escaped criticism. Erwin Chemerinsky, Pedagogy Without Purpose: An Essay on Professional Responsibility Courses and Casebooks, 1985 AM. B. Found. RES. J. 189; Erwin Chemerinsky, Training the Ethical Lawyer: A Rejoinder to Schneyer, 1985 AM. B. FOUND. RES. J. 959. But see Ted Schneyer, Professional Responsibility Casebooks and the New Positivism: A Reply to Professor Chemerinsky, 1985 AM. B. FOUND. RES. J. 943.

13. See Robert H. Aronson, New Dimensions in Legal Ethics: Role Playing in Teaching Professional Responsibility, LEARNING \& L. Fall 1975, at 50, 52.

14. E.g., ThOMAS L. SHAFFER, AMERICAN LEGAL ETHICS: TEXT, READINGS AND DisCUSSION TOPICS (1985); Vincent Robert Johnson, Law-givers, Story-tellers, and Dubin's Legal Heroes: The Emerging Dichotomy in Legal Ethics, 3 GEO. J. LEGAL ETHICS 341 (1989). 
al Responsibility contributed to the community's cohesion and facilitated communications among academics, members of the organized bar, and regulatory authorities by sponsoring an annual conference devoted exclusively to professional responsibility and organizing programs at the ABA's annual and mid-winter meetings. The practicing lawyers who attended these meetings were often members of law firm or bar association ethics committees or specialized in legal malpractice litigation. Disciplinary authorities found these meetings to be particularly helpful because they provided an overview of ethical developments nationwide and facilitated an exchange of information on technical advances and innovations. The conferences and meetings thus created a multidimensional learning environment, benefitting teachers of professional responsibility, practicing lawyers, and bar counsel.

Until recently, two methods of instruction dominated most law school classrooms: the pervasive method and the survey-course method. Proponents of the pervasive method argue that the most effective way to expose students to their future ethical responsibilities is to raise professional responsibility issues and discussions in all substantive courses. For example, civil procedure professors are encouraged to talk about the genuineness of the attorney-client relationship in the context of class actions, ${ }^{15}$ insurance professors are invited to discuss conflicts of interest between insurers and insureds; ${ }^{16}$ contracts professors are asked to analyze the ethical parameters of negotiations; ${ }^{17}$ and tax professors are urged to address the ethics of estate planning. ${ }^{18}$ Even legal writing can be an occasion for professional responsibility instruction. ${ }^{19}$ The opportunities for ethical reflection are legion in clinical instruction. ${ }^{20}$

Professor Rhode, the premier scholar in this area, has forcefully argued:

The primary rationale for addressing ethical issues throughout the curriculum is that they arise throughout the curriculum. In law, professional responsibility considerations figure in all substantive areas. Treating those considerations as they emerge in conventional classroom analysis can make clear that they are crucial constituents of practice and can expose students to a broad range of faculty perspectives. ${ }^{21}$

15. E.g., Richard A. Matasar, Teaching Ethics in Civil Procedure Courses, 39 J. LEGAL EdUC. 587, 604-05 (1989).

16. E.g., Robert N. Covington, The Pervasive Approach to Teaching Professional Responsibility: Experiences in an Insurance Course, 41 U. COLO. L. REV. 355 (1969).

17. E.g., Scott J. Burnham, Teaching Legal Ethics in Contracts, 41 J. LEgal EdUC. 105, 112-15 (1991).

18. E.g., Lester B. Snyder, Teaching Professional Responsibility in Tax Courses, 41 U. COLo. L. REV. 336 (1969).

19. See Margaret Z. Johns, Teaching Professional Responsibility and Professionalism in Legal Writing, 40 J. LEGAL EDUC. 501 (1990); see also Nancy M. Maurer \& Linda Fitts Mischler, Introduction to Lawyering: Teaching First-year Students to Think Like Professionals, 44 J. LEGAL EDUC. 96 (1994) (describing an integrated clinical and legal writing program that includes a significant professional responsibility component). (1994).

20. E.g., Steven Lubet, Ethics and Theory Choice in Advocacy Education, 44 J. LEGAL Educ. 81

21. Rhode, supra note 2, at 50; see also David T. Link, The Pervasive Method of Teaching Ethics, 39 J. LEGAL EDUC. 485 (1989). The pervasive method's detractors have frequently raised the specter 
Proponents of the survey-course method argue that the pervasive method is well intentioned but fatally flawed. First, it would be impossible to monitor each full-time and adjunct faculty member's classroom without excessive intrusion. Second, to be effective, it would require extraordinary cooperation among faculty members to ensure that students were exposed to a complete curriculum before graduation and to avoid repetition of the same issues in different courses. ${ }^{22}$ Third, the amount of time devoted to ethical issues would inevitably be a function of the pace of each year's courses, with no guarantee of similar coverage from year to year. ${ }^{23}$ Finally, to implement a pervasive curriculum successfully, teachers would have to invest substantial time in mastering the subject matter and keeping abreast of the latest developments. ${ }^{24}$ Their criticisms have carried the day, according to a 1985 nationwide survey of professional responsibility teaching, which showed that 95 percent of all ABAaccredited law schools required the successful completion of a separate professional responsibility course as a condition of graduation. ${ }^{25}$

The pedagogic assumption underlying survey courses is that law schools can best prepare students to wrestle with the multitude of law-of-lawyering dilemmas they will encounter by exposing them to ethical and liability conundrums in a deliberate mix of practice environments. ${ }^{26}$ The standard survey-course curriculum is all-embracing in two senses. The substantive-law units contain materials in an array of practice settings (such as criminal, corporate, or matrimonial law) and employment sectors (such as solo-, small-, and mega-firms, government offices, and corporate counsel).

that "a single ethics-legal profession teacher might subvert the students," Theodore A. Smedley, The Pervasive Approach on a Large Scale: "The Vanderbilt Experiment," 15 J. LEGAL EdUC. 435, 437 (1963), and condemned "the misguided dedication of some teachers which leads them to indoctrinate rather than to teach professional responsibility," James E. Starrs, Crossing A Pedagogical Hellespont via The Pervasive System, 17 J. LEGAL Educ. 365, 370 (1965).

22. For a candid description of the enormity of such an undertaking, see Smedley, supra note 21, at 437 .

23. The comment of a graduating third-year student at one leading law school succinctly captures this difficulty: "'[T]he pervasive method' at Stanford means that professors schedule 'ethics' on the syllabus for the last day of class and then run out of time." Will Needle, Maybe I Missed the Day We Did Ethics, STAN. L.J., Feb. 1991, at 11.

24. Cf. Starrs, supra note 21 , at 370,373 ; see also Rhode, supra note 2, at 51-53. The more likely scenario is to "invite [] the poor sap who teaches Professional Responsibility into each course at least once a semester to do something ethical with the students." Jack L. Sammons, Jr., Professing: Some Thoughts on Professionalism and Classroom Teaching, 3 GeO. J. LEGAL ETHICs 609, 610 (1990).

25. ABA CENTER for Professional Responsibility, A SuRvey on the Teaching of PROFESSIONAL RESPONSIBILITY 3 (1986). An earlier survey reported similar findings. Stuart C. Goldberg, 1977 National Survey on Current Methods of Teaching Professional Responsibility in American Law Schools, in TEACHING PROFESSIONAL RESPONSIBILITY: MATERIALS AND PROCEEDINGS from National LaWyers CONFERENCE 23, 32 (Patrick A. Keenan ed., 1979).

26. As two commentators have correctly noted:

Although there may not be an archetypical ethics course, there seems to be some consensus that it should encompass: (1) the "doctrine" (the Model Code, the Model Rules, constitutional requirements, other pertinent statutes, case law, and ABA opinions), (2) the history and sociology of the legal profession, and (3) the morality of the lawyer's role. Ian Johnstone \& Mary Patricia Treuthart, Doing the Right Thing: An Overview of Teaching Professional Responsibility, 41 J. LEGAL EDUC. 75, 90 (1991). 
While not disputing the standard curriculum's value, this essay argues for a new pedagogy: contextualization of the curriculum. This alternative curriculum proposes a studied examination of ethical dilemmas in a single practice area.

III

\section{A Professional Responsibility CuRriculum for the Twenty-First CENTURY: THE FORDHAM INITIATIVE}

The history of the professional responsibility curriculum at Fordham initially resembles that of many other law schools. From 1974, when the ABA adopted Standard 302(a)(iii), until 1987, Professional Responsibility was a one-credit course focusing almost entirely on the New York Code of Professional Responsibility. It was a mandatory second-year course. No one was happy with its credit or coverage. The students complained that the course was irrelevant and a waste of time. The faculty members assigned to teach the course acknowledged some validity in students' criticisms and eventually concluded that the students' hostile attitude to the course required a complete revamping of the professional responsibility curriculum; more was needed than an additional credit and expanded coverage.

Beginning in 1988 and over the course of several years, Fordham applied the bedrock pedagogical principle that student excitement is directly proportional to faculty commitment: Fordham recruited faculty who were committed specifically to teaching and scholarship in the area of professional responsibility. ${ }^{27}$ Their presence demonstrated that Fordham as an institution regarded Professional Responsibility with the same seriousness as it did other core courses, such as Corporations, Contracts, or Constitutional Law.

The new faculty put their collective mind to the task of surveying other law schools' curricula in a search for successful models. The search proved short, and the landscape bleak. Student disdain was commonplace, punctuated by occasional applause for classroom innovations, frequently involving the use of video vignettes or role-playing. Since the outside world had not found the successful professional responsibility curriculum, we decided to look inside: We asked what made courses "successful" at Fordham ${ }^{28}$ and concluded that intellectual engagement in upperclass courses was generally a function of a student's perception (1) that the teacher genuinely cared about the subject

27. Fordham was particularly fortunate that three existing faculty members already had a strong interest in professional responsibility. Professors James Cohen and Abraham Abramovsky have taught the survey course from time to time and bring to their classes a wealth of insights from their teaching and scholarly writings in clinical and criminal law, respectively. Professor Daniel Capra teaches the survey course once each academic year. A well-known scholar in both civil procedure and evidence, he has devoted significant amounts of time to participating in and chairing bar association professional responsibility committees. His joining of scholarly and practical knowledge enriches the survey course immensely.

28. "Successful" is not synonymous with "popular." The successful courses we strove to emulate were intellectually rigorous, demanded significant reading, and insisted upon classroom participation. 
matter, the students, and what went on in the classroom, (2) that the subject matter was intellectually rigorous, and (3) that it related to their career options in some tangible fashion. This final factor of career-relatedness particularly influenced students' course selection decisions except those relating to perspective courses such as Jurisprudence, Constitutional Theory, or Feminist Legal Theory. Career-relatedness, however, was clearly distinguishable from "practice" or "skills" training; students were not expecting substantive law courses to teach them how to draft SEC registration forms, criminal indictments, or class-action complaints in employment discrimination cases. For that training, they enrolled in clinical offerings. They enrolled in substantive law courses because they wanted to assess their intellectual interest and comfort level in a particular area of the law.

That insight prompted us to develop two contextual courses and two contextual seminars set in different practice sectors: business, criminal, and public interest. ${ }^{29}$ Each offering is worth three credits, as is the traditional survey course that still plays an important role in the curriculum. While adjustments are made on a year-to-year basis to accommodate faculty needs such as sabbaticals and committee assignments, the contextual courses and seminars are offered as frequently as possible to enable the maximum number of interested students to enroll. Thus, in the fall semester, we generally schedule two sections of the professional responsibility survey course and one section each of Professional Responsibility in Corporate, Business, and International Transactions, Ethics in Public Interest Law, and Ethics in Criminal Advocacy. In the spring semester, we offer an advanced seminar in public interest law, the survey course, and Professional Responsibility in Corporate, Business, and International Transactions.

The student and faculty responses to the contextual courses have been uniformly high. As mentioned earlier, the students are enthusiastic and work harder. Choice, as expressed through the availability of different courses, plays an instrumental role in their receptiveness. It significantly diminishes the psychological burden that upperclass mandatory courses often carry with them. Choice also signals faculty recognition of the intellectual weightiness of a subject-matter area. It dresses Professional Responsibility with the same cloak of academic respectability as Constitutional Law or Property. Few faculty members or students consider courses in first amendment law or advanced real estate financing out of the ordinary. Why should they hold a different opinion of professional responsibility?

In constructing the syllabi for the courses described above, our goals were threefold. First, we believed it was important for the students to master

29. Through the generosity of the W.M. Keck Foundation, Fordham received a grant in 1994 to refine each offering's curriculum and prepare course materials and syllabi for three additional offerings: Ethics in Tax and Regulatory Matters, Lawyering for Individuals, and Judicial Roles and Responsibilities. We anticipate introducing these new offerings into the curriculum over the next year and a half. 
fundamental law-of-lawyering concepts, such as confidentiality, conflicts, and duties to nonclients. Second, we wanted the students to appreciate the structural underpinnings of the legal profession and how economic and political forces shape them. Third, we wanted them to grapple with justice issues, particularly the delivery of legal services to the poor and the middle class, the concentration of legal "wealth" in the hands of a relatively small percentage of the population, and the soundness of the advocacy model as a device for truthfinding. With these shared goals in mind, each professor has created individual textbooks consisting of excerpts from cases, bar association ethics committee opinions, and law review articles. ${ }^{30}$ Thus, the "feel" of the textbook and the assigned readings in a contextual course is no different from that in any professional responsibility survey course. In addition to the textbook, students are required to purchase a selected standards volume containing the ABA Model Code and Model Rules and other relevant regulatory pronouncements.

In proposing context-specific courses and in constructing our syllabi, we constantly dodged one nagging doubt. We fretted over the long-term effect of the courses' single practice setting. We had no way of knowing whether our students would actually secure employment in the same practice setting as their professional responsibility course, especially in light of the current cutbacks in public sector jobs. Even if they did, today's graduates face uncertain career paths and are likely to practice in several different settings. We worried, for example, that a student who took Ethics in Public Interest Law would be less sensitive to professional responsibility issues in entity representation if she went to work in an in-house law department or conversely, that a student in the corporate, business, and international course would be less sensitive to ethical issues in criminal practice if he became an associate in a white-collar defense firm. We addressed this concern by deliberately including cross-references to other practice settings in lectures and class discussion. Now that we have taught the contextual courses for several years, we worry a great deal less—or not at all-about this potential isolation. The range and sensitivity of the students' ethical "antennae" do not appear to be diminished by the concentrated pedagogy.

In the remainder of this essay, we describe each contextual course more fully. We have reserved our lengthiest description for the Advanced Seminar in Ethics and Public Interest Law because of all four offerings, it is both the most innovative and labor intensive.

30. We have shared our syllabi with professional responsibility teachers in over a dozen different law schools. Readers who would like copies should not hesitate to request them. Professor Daly teaches Professional Responsibility in Corporate, Business and International Transactions; Professor Green teaches Ethics in Criminal Advocacy; and Professor Pearce teaches Ethics in Public Interest Law.

Professors Green and Pearce co-teach the advanced seminar in ethics and public interest law. 


\section{IV \\ DESCRIPTION OF THE COURSES}

\section{A. Professional Responsibility in Corporate, Business, and International Transactions}

This offering is fundamentally an exercise in imagination, inviting students to visualize themselves over the course of the next five, ten, and twenty years as "Wall Street Lawyers" and "Main Street Lawyers," as litigators, counselors, and advisers, as law firm partners and associates, as in-house counsel, and as clients. Constructed around the types of ethical dilemmas commonly encountered by lawyers who represent entities or individual entrepreneurs, it exposes students to a broad range of practice settings and lawyering tasks. It is a quintessential law-of-lawyering course. The curriculum incorporates statutory, regulatory, and common law topics as well as traditional code-of-conduct topics such as confidentiality, conflicts, fees, and duties to nonclients. Macro issues are emphasized through classroom debates about pro bono responsibilities, the adequacy and efficiency of current admission and disciplinary systems for regulating the conduct of business lawyers, and the role of business lawyers in policing their clients and protecting the public.

The course consists of three major units-core concepts, contextual dilemmas, and law-and-economic analysis. We introduce the course with excerpts from Heinz and Laumann's classic study, "Chicago Lawyers." 31 The students generally react quite positively to the authors' description of the two hemispheres of the legal profession separately composed of lawyers who represent individuals and small businesses and those who represent large organizations. The students' own observations generally confirm the striking dissimilarities between the hemispheres in terms of professional "prestige" and the organizational structure and lawyering strategies of their law firm inhabitants. On the very best of classroom days, these excerpts provoke a discussion of professional elitism and class within the New York bar and at the national level. To the extent that the students perceive the legal profession to be endorsing "Wall Street" over "Main Street," these discussions facilitate individual reflections on social stratification within the bar and assessments of emotional contentment with anticipated career choices.

The next several weeks are devoted to core concepts: organizations as clients; confidentiality; conflicts; and fees. Initially, the students are assigned the introductory and advanced Computer Assisted Legal Instruction ("CALI") exercises on the Model Code of Professional Responsibility and the Model Rules of Professional Conduct. Classroom discussions and analysis of the core

31. John P. Heinz \& Edward O. LaUmann, Chicago Lawyers: The Social Structure of THE BAR (1982). 
concept materials thus assume the students' basic familiarity with those tenets. A quick glance at the syllabus illustrates' the difference between this approach and the traditional survey course. No citation to the "Dead Bodies" case or Fiandaca $v$. Cunningham ${ }^{32}$ appears in the text's table of contents. In their place is an extensive excerpt from the Report of the Trustee in the OPM bankruptcy, ${ }^{33}$ the full texts of four recent ABA opinions on confidentiality, ${ }^{34}$ and In re Infotechnology. ${ }^{35}$ The hypotheticals that spark class discussion bear a striking resemblance to the charges and denials in the Kaye Scholer matter or to other current business-lawyer events. ${ }^{36}$

The first and second units sharply contrast. The core-concept materials generally ignore distinctions in practice and employment settings, although all are "business law" related. On the other hand, these distinctions are at the heart of the context-specific second unit. It consists of five chapters, each one addressing separately ethical issues in securities law, hostile takeovers, negotiations, cross-border practice, and in-house practice. ${ }^{37}$

The third unit, entitled the "Future of the Corporate Law Firm," serves two very different pedagogical goals. The first is to introduce students to law-andeconomics analysis as applied to the legal profession. ${ }^{38}$ Thus, the reading materials are almost exclusively drawn from law review articles and books and include excerpts from the classic works of writers such as Marc Galanter, Thomas Palay, Robert Nelson, and Ronald Gilson. The second goal is to spur the students, both male and female, to reflect on the emotional pressures they can expect to experience over the course of their careers, especially in the next ten years. Topics explored include the effects of the spiraling demands by law firms for "billable" hours on associate and partner life-styles, the mommy-track,

32. People v. Belge, 376 N.Y.S.2d 771 (4th Dep’t 1975), aff d, 390 N.Y.S.2d 867 (1976); Fiandaca v. Cunningham, 827 F.2d 825 (1st Cir. 1987).

33. In re OPM Leasing Services, Inc. Report of the Trustee Concerning Fraud and Other Misconduct in the Management of the Affairs of the Debtor (S.D.N.Y. 1983); Stuart Taylor, Jr., Ethics and the Law: A Case History, N.Y. TIMES, Jan. 9, 1983, Sec. 6 (Magazine), at 30.

34. ABA Comm. on Ethics and Professional Responsibility, Formal Ops. 92-366 (1992), 93-375 (1993), 93-376 (1993), 94-380 (1994).

35. 582 A.2d 215 (Del. 1990).

36. The Wall Street Journal, Fortune, and Business Week routinely publish articles on the legal profession, prominent lawyers, and significant business cases and transactions. They are a fertile source for class discussions (and examination questions). The course's "real-life" ambiance particularly appeals to students. A painless way to maintain that ambiance is to construct a clipping file using either the LEXIS or WESTLAW magazine and newspaper databases. Discussions on LEXIS Counsel Connect are helpful not only in identifying cutting-edge issues, but also in bridging the divide between the academy and the bar.

37. The particular choice of these areas was a matter of personal preference. Other teachers might prefer chapters, for example, on ethical issues in real estate, intellectual property, or tax practice. It is hard to imagine this course, however, without a chapter exploring the ethical obligations of securities lawyers and in-house counsel.

38. The course has no specific chapter dealing with legal fees. However, by this point in the syllabus, the topic has usually been discussed for about one hour in connection with a case or transaction that has received press notoriety during the current semester. Thus, the students have been exposed to economic analysis and the "promotion-to-partner tournament" before this unit is assigned. 
and why women lawyers tend to leave large law firms at greater rates than their male colleagues.

Deciding how and where to teach the international material in this curriculum has been difficult. ${ }^{39}$ After some experimentation, we concluded that combining the pervasive and the context-specific approaches works best. At the beginning of the course, the students are assigned the Code of Conduct for European Lawyers promulgated by the Council of the Bars and Law Societies of the European Community. During the core-concepts part of the course, references are made to the appropriate articles of the Code and comparative insights are offered whenever possible. In the context-specific part, a chapter is devoted specifically to ethical issues in cross-border practice.

Finally, there are a number of well crafted video programs that are used to stimulate class discussion. For example, we usually show "The Saga of Albinex" on the first day of class. ${ }^{40}$ It pointedly and poignantly captures several basic dilemmas in entity representation and partner-associate relationships. The ABA Center on Professional Responsibility has produced timely vignettes on, inter alia, conflicts and confidentiality. The Corporation for Public Broadcasting has an excellent series on ethical dilemmas in different professions, including the law. A favorite of the students (and ours) is the round-table program on hostile takeovers; it brings the giants of business law, such as Joseph Flom and Arthur Liman, into the classroom and allows the students to eavesdrop on animated defenses and critiques of the merger and acquisition era by T. Boone Pickens, Joseph Gutfreund, and other prominent clients.

\section{B. Ethics in Public Interest Law}

Ethics in Public Interest Law explores the distinctive role of, and ethical challenges facing, public interest lawyers. The course defines public interest law broadly. The curriculum is drawn from cases and materials dealing with the work of lawyers in various fields, including poverty lawyers, lawyers for historically oppressed communities, lawyers for social change, lawyers for children and the elderly, and civil government lawyers.

The teaching philosophy is that students learn best when they are responsible in significant part for the work of the class, when they experience ethical dilemmas through ${ }^{\prime}$ role-play and simulation, and when they engage practitioners in dialogue regarding the theoretical issues discussed in class. We have a

39. The decision to include materials relating to cross-border practice was prompted by the increasing importance of private international practice. According to the Department of Commerce, U.S. law firms collected $\$ 1.4$ billion from foreign clients in 1992 alone. Legal services ranked fourth on the Department's list of highest grossing export businesses and professional services. Gary Taylor, U.S. Firms Are Export Machines: Sale of Legal Services Abroad Soars in the ‘90s, NAT'L L.J., May 30, 1994, at 6. Cross-border legal services are one of the few growth areas for law firms in the present, otherwise stagnant, marketplace.

40. The Saga of Albinex is one of several ethics tapes produced by the Center for Professionalism at the University of Pennsylvania School of Law. It is particularly suited for showing in a course examining ethical conflicts in entity representation. 
standard curriculum only for the first few weeks of class. Thereafter, with the exception of the discussions with practitioners, the class is based on student presentations. We urge the students to use role-play and simulation for their presentations, and we work with them in preparing for class. The students are also responsible each week for one paper, which responds to the readings or to the class presentations. The response paper has proved to be invaluable in focusing the students on the issues being discussed, especially for those who are not presenting that week. It also provides immediate feedback on the progress of the class. In addition, the students must complete a twenty-page research paper. Finally, the students must complete a six-hour CALI ethics course to ensure that they are familiar with areas of black-letter ethics law not covered in class.

In order to create a classroom atmosphere in which students feel comfortable enough to speak honestly, the class first focuses on how issues of race and gender influence their experience as law students. The discussion then moves to a review of articles exploring the influence (or lack thereof) of race and gender on a lawyer's role. Student presenters follow, creating role-plays that raise the same issues for public interest practice. ${ }^{41}$ The course then moves to a consideration of the various potential goals lawyers might choose for their roles, including advocacy, governing class, feminist, religious, and empowerment, and a consideration of how these roles do or should apply to the decisions public interest lawyers make. Some specific questions relating to role include whether the traditional model of representing individual clients applies to public interest lawyers, whether government lawyers represent the public as well as the government, and whether legal services or civil rights lawyers exceed the bounds of their role as an attorney (or best fulfill that role) when they promote law reform litigation rather than individual representation.

Like the other context-specific offerings, Ethics in Public Interest Law generally covers the same topics as the traditional survey course; however, the particular issues, cases, and materials are from the public interest setting. For example, the course devotes at least one week each to issues that arise in the representation of groups, children, and persons with mental health disabilities, to issues regarding government entities in civil matters, and to issues of competence and role in setting priorities for poverty law offices. In covering confidentiality, the course examines the poverty lawyer's duties when a client is defrauding the government, the effect of the public's right-to-know on the government lawyer's confidentiality obligations, and the lawyer's First Amendment rights. In covering conflicts of interest, the course considers whether a

41. This format has worked quite effectively over the years. Professor Pearce developed it based on an earlier program he had created with Professor David Thomas of the Harvard Business School, Robin Ely of the John F. Kennedy School of Government at Harvard, and Elaine Wakura of the UCLA Sloan School of Management. They had collaborated in creating the professional responsibility component of the first-year Ethics and Professionalism program at the University of Pennsylvania School of Law. 
legal services organization should represent separate indigents with conflicting interests if otherwise one of the clients would be denied representation; the course also considers the obligations of a government lawyer whose clients' interests conflict.

The last section of the course discusses issues of access to justice and the distribution of legal services. Depending on their interests, students offer presentations on topics such as legal services for middle income persons, assisting pro se litigants, deregulation of legal services, alternative dispute resolution, mandatory pro bono, and attorney's fees.

\section{Ethics in Criminal Advocacy}

This seminar examines issues of professional ethics principally from the perspective of prosecutors and defense lawyers (while making occasional reference to lawyers in other roles as a basis of comparison). One of the seminar's virtues is that the ethical issues facing prosecutors and defense lawyers tend to be among the most interesting for students. Another virtue is that the role differences between prosecutors (who have a duty to "seek Justice") and criminal defenders (who are the quintessential "zealous advocates") result in dramatic differences in the applicable professional norms.

The readings include selected rules and standards of professional conduct, such as the ABA Model Code and Model Rules, the ABA Criminal Justice Standards, and the American Trial Lawyers Association rules. Additionally, students receive a separate textbook consisting of problems, judicial decisions, opinions of state bar association ethics committees, and excerpts from law review articles and books that have been collected over the course of several years and are updated annually. The readings provide points of departure for class discussions and role-playing exercises. In addition to leading class discussions, students in the seminar are required to complete a substantial research paper.

Various issues inevitably emerge in the course of class discussions. They include the following: the limitations of enforcing professional norms; the vast range of discretion afforded lawyers by professional norms; the interrelationship between "law" (such as constitutional law, criminal law, torts, and evidence) and ethical rules; role-differentiation; and the context-specificity of professional norms. Students develop heightened sensitivity to the array of ethical issues that lawyers face, come to a better understanding of the importance and difficulty of responding appropriately, and become familiar with the sources of guidance available to help formulate appropriate responses.

D. Advanced Seminar in Ethics and Public Interest Law

This seminar is offered to upperclass students who have already completed a three-credit course in professional responsibility and is required for students 
in the Stein Scholars Program. ${ }^{42}$ Each year, the seminar examines questions relating to professional responsibility, professional values, and professional role in a different public interest law context. In its first year, the seminar examined questions in the context of legal services for the elderly and in its second year, in the context of legal services for children. Typical questions include: Are the rules of ethics different, or influenced by the absence of a profit-making motive, on one hand, and the need for government or outside funding, on the other? How does representation provided without a fee, by an organization that may be the only available source of legal services for indigent clients, affect the lawyer-client relationship? How does such an organization allocate its limited resources? And how do the organizations' responses to these questions comport with traditional lawyering norms?

The students explore these questions in the seminar through a process of collaborative research and cooperative learning. They are expected to assume a high degree of responsibility for the direction of both their individual work and the class. The approach we take reflects the view that student-to-student learning and student-initiated learning are pedagogically most productive.

The seminar's goals are essentially two-fold: First, it is designed to explore ethics in public interest law at an advanced level. Thus, the seminar assumes that in previous classes, students have attained a basic familiarity with lawyers' ethical obligations and with the structure and regulation of the bar. Building upon this knowledge, students undertake an assessment of what public interest law offices actually do in light of professional norms and a critique of the legal literature in light of what the offices actually do. Anecdotal material gathered from various sources is an essential component of the students' research.

Second, the seminar strives to enable the students to work toward developing various skills identified in the "MacCrate Report."43 These skills include legal analysis and reasoning, legal research, communications, organization and management of legal work (particularly, developing systems and procedures for effectively working with other people), and recognizing and resolving ethical dilemmas.

In its first year, the seminar examined legal services offices for the elderly and was conducted as follows: At the outset, the students were provided with reading materials that enabled the group to identify discretionary decisions made by lawyers and legal services offices representing older clients. The readings also helped to identify factors that might influence how those discretionary decisions were made. Each of the fifteen students in the seminar

42. The Stein Scholars Program is a three-year program for specially selected students who work in public interest law settings during their law school careers and undertake specialized academic work in legal ethics. The students assume significant responsibility for developing pro bono projects, organizing and moderating roundtable discussions of pertinent issues in legal ethics and public interest law, and publishing newsletters on these issues.

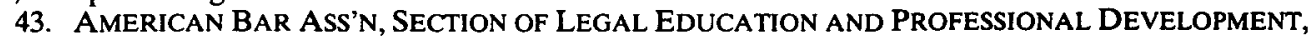
AN EDUCATION CONTINUUM: REPORT OF THE TASK FORCE ON LAW SCHOOLS AND THE PROFESSION: NARROWING THE GAP (1992). 
was then paired with a lawyer who had agreed to be interviewed several times over the course of the semester and to discuss how decisions were made and cases were handled. Each lawyer was from a different office in a different part of the country. The students were instructed to interview the lawyer concerning the range of issues identified by the class and to distribute a detailed summary of the information provided. To assist the students in structuring the interviews, two practitioners were the subject of mock interviews at a class in the early part of the semester.

In the first few classes, information learned in the course of the interviews was pooled and the issues to be addressed by the seminar were refined through faculty-moderated discussions. Five broad topics were identified, and the class was then divided into five groups of three students each. Each group was assigned a different topic and instructed to prepare one or more papers compiling the anecdotal material developed by all the seminar students on that topic and to analyze that material in light of professional standards, the legal literature in the area, and other writings. The students were free to decide whether to work together as a group or to subdivide their topics.

In the middle weeks of the seminar, each of the five groups directed one class discussion. The groups distributed various readings in advance of class and proceeded through combinations of role-playing, discussion, and lecture. Some class time was also reserved each week to explore interesting issues or difficulties that had arisen in the course of the other students' interviews or research.

In the final classes, the students (having decided to work individually on a separate research topic) presented the work they were doing. Topics included, inter alia, the use of hotlines, paralegals, and outreach programs, the use and function of retainer agreements, how offices decided which clients and client matters to accept, how offices identified and resolved ethical issues, how funding sources influenced attorney discretion, how decisionmaking was allocated between lawyers and competent clients, and how lawyers dealt with incapacitated clients. The students' ongoing work was discussed by the class, and suggestions were made by the professors about additional questions to consider or material to read. Toward the end of the semester, one of the professors also provided his own reflections about the common themes that had emerged from the interviews and the students' research.

In the end, the students amassed considerable amounts of anecdotal material that revealed-somewhat to their surprise-a wide range of practices among offices and individual lawyers serving similarly situated clients. Student evaluations of the course reflected two principal criticisms: that the project was too daunting and demanded too much time for a three-credit course, and that the class itself seemed too unstructured, particularly at the outset. Notwithstanding these concerns, however, almost all the evaluations were extremely positive. Particular appreciation was expressed for the opportunity to have conversations with "real lawyers" and to work closely with fellow students. 
In its second year, the seminar was restructured to respond to these criticisms. In advance of the first class, students were provided with an outline describing ethical issues in the legal representation of children. Among the issues identified were problems concerning the allocation of decisionmaking between the lawyer and the child or the child's parents, the determination of whether a child has the capacity to make decisions relating to the representation, the lawyer's determination of the child's best interests for purposes of making decisions or counseling the child about decisions, the interviewing and counseling of the child client, and confidentiality and conflict of interest issues. The students also received some reading materials relating to those issues as well as a bibliography of additional materials. The result of these changes was that in the second year, the students were able to discuss and analyze the issues confidently at a much earlier stage in the seminar.

During the first class meeting, the students divided into groups of two, three, or four to address one of the issues we had identified or a new problem of their own choosing. Additionally, each student was matched with a different lawyer whose practice involved the representation of children and was required to interview the lawyer several times during the semester. In this year, as in the prior one, we invited two lawyers to provide the students with a "dry-run" in conducting the interviews.

As the seminar progressed, a child psychologist was invited to the class to provide a different discipline's perspective. Students were also assigned to visit a law office in New York City that represents children. Class time was devoted to discussing possible guest speakers, the law-office observations, and the interviews conducted over the course of the semester. Students were also required to prepare and submit a weekly journal that responded to any aspect of the seminar, such as the readings or the class discussions.

In contrast to the first year, each of the small groups was required to make two presentations (and to distribute relevant readings in advance of the presentations). The first presentation was designed to familiarize the other students with the issues each group was addressing and to elicit discussion about the issues. The groups approached the presentations in different and often creative ways. One group brought in an adolescent acting troupe to assist in a role-playing exercise. Another invited a judge who had issued a conflict-ofinterest decision that was under study to speak to the class. The second presentation focused on the students' independent research. In general, the research combined relevant material from the interviews conducted with additional readings in legal and, in many cases, non-legal literature. The seminar culminated in the submission of final papers by each student. Several lawyers were invited to the final class meeting to hear and respond to the conclusions drawn in the papers.

At the conclusion of the seminar, the students submitted detailed evaluations. They were extremely positive. However, as in the prior year, the students criticized the extent of the workload relative to its three credits and 
several suggested that, like "clinical courses," the seminar should be allocated more credit-hours. With the sole exception of the weekly journals, the students concluded that every component of the seminar contributed significantly to their understanding. Although the journals were not particularly useful from the students' perspective, they were important from ours since they provided weekly feedback on whether the goals of the class were being met, allowed us to direct discussions to take advantage of insights or to address concerns reflected in the journals, and facilitated private communication about problems that the students were uncomfortable discussing publicly. The latter role was particularly important because on occasion, students found the classes personally distressing, in that they brought to the surface problems in the students' own family lives or problems in the students' relationship with others in the class or the law school.

From the perspective of both students and professors, the interviews of practitioners were most valuable, although the students universally grumbled about the amount of time devoted to transcribing them. Having to conduct a series of interviews motivated the students to develop some sophistication in the issues they were discussing in order to impress the interviewees, or, at the very least, to avoid embarrassing themselves. The stories and perspectives offered by the practitioners enabled students to see the relationship between published professional norms (which on their surface seem so easy to apply) and the vagaries of real practice. The students came to appreciate the vast discretion afforded by the professional norms, the inadequate guidance they afford, and the range of approaches undertaken by lawyers with respect to issues that are tremendously important and sensitive. The anecdotal accounts provided students with a springboard for their research papers. And through in-class discussions of the interviews, students refined their critical (and self-critical) abilities in addressing issues of professional practice. Virtually every student initially approved of the approaches taken by his or her interviewee-typically referred to as "my lawyer"; however, a comparison of approaches, the questions raised by their classmates, and their independent research and analysis eventually made students more skeptical.

Many students believed the class contributed to their development of various lawyering skills, such as legal analysis and reasoning, legal research and writing, and oral communication. However, the particular benefit consistently identified by students was the development of their understanding of the significance that ethics, professional role, and professional and personal values play in the practice of law.

\section{$\mathrm{V}$ \\ CONCLUSION}

Over the course of the last twenty-odd years, professional responsibility teachers have struggled to gain the respect of the academic community, the organized bar, and their students. They have won that battle for the most part. 
It is time to move on-to demonstrate the intellectual richness and complexity of the subject matter in a different way.

During this same period, economic, political, and social forces have radically altered the structure and pratice milieu of the legal profession. Today, very few lawyers in the private sector can legitmately claim the title of "generalist." It is humanly impossible for a single lawyer to master the unceasing changes in statutes, administrative regulations, and case law that impact the commercial and personal decisionmaking of the lawyer's clients. On a daily basis, public interst lawyers, prosecutors, and defense counsel must analyze an immense and complex body of constitutional principles, statutes, and judicial opinions. As the legal profession enters the twenty-first century, this explosion in the law has forced lawyers in all practice areas and employment settings to focus their expertise more narrowly. This shift is transforming how lawyers percieve themselves and how they practice. To respond to the shift, the academy must develop a new approach to teaching professional responsibilty.

Contextualization meets the needs of both the academy and the organized bar. It exploits the intellectual richness and complexity of the subject matter. It excites the students' moral imagination, prompting commitment to the reading assignments and invigorating classroom discussions. At the same time, contextualization prepares students for their careers by exposing them to the ethical dilemmas associated woth focused practice areas. It also contributes to satisfying the organized bar's demand for greater practice-related instruction in law schools. In sum, contextualizing professional responsibility secures a new curriculum for a new century. 
